\title{
HUBUNGAN SEROTINUS DENGAN KEJADIAN ASFIKSIA BAYI BARU LAHIR DI RUMAH SAKIT UMUM DAERAH KOTA KENDARI TAHUN 2015
}

\author{
Elyasari $^{1}{ }$ Listi $^{2}$ \\ ${ }^{1}$ Dosen Jurusan Kebidanan Poltekkes Kemenkes Kendari \\ ${ }^{2}$ Mahasiswa Jurusan Kebidanan Poltekkes Kemenkes Kendari
}

\begin{abstract}
Background: Newborn asphyxia is a condition where the baby is born can not immediately breathe spontaneously and regularly after birth (Wiknjosastro, 2007). AKB in Kendari City in 2014 as many as 26 people out of 6,228 newborns with the incidence of asphyxia in newborns in Kendari City General Hospital in 2015 as many as 78 people out of 950 newborns and the number of infants experiencing serotinus as many as 40 babies (Medical Record of Kendari City Hospital, 2015).

Objective: To determine the relationship between serotinus and the incidence of asphyxia in newborns at the Kendari Regional General Hospital in 2015.

Research methods: The type of research used was analytic with the design of Case Control. The sampling technique was purposive sampling, in which all asphyxial infants were taken as a case. The systematic sampling technique was random sampling, where all non-asphyxial infants were numbered, and from 872 non-asphyxial infants divided by the number of controls taken $872: 78=11.2$, so that the sample for control is a multiple of 11 .

The results of the study: based on data analysis obtained results, namely from 78 infants with asphyxia there were 10 people $(12.8 \%)$ babies born with serotinus. The value of $\mathrm{X}^{2}$ counts $5,778>\mathrm{X}^{2}$ table 3,841 so that $\mathrm{H} 0$ is rejected and Ha is accepted with $\mathrm{OR}=5.588(p=0.032)$.

Conclusion: There is a relationship between serotinus and the incidence of asphyxia in newborns in Kendari Regional General Hospital in 2015
\end{abstract}

Keywords: asphyxia, serotinus

\section{PENDAHULUAN}

Asfiksia bayi baru lahir merupakan keadaan dimana bayi lahir tidak dapat segera bernapas secara spontan dan teratur setelah dilahirkan (Wiknjosastro, 2007).

Faktor penyebab kegagalan pernapasan pada bayi asfiksia dapat terjadi karena beberapa faktor yaitu faktor ibu seperti preeklampsia dan eklampsia, pendarahan abnormal (placenta previa dan solution placenta), demam selama persalinan, infeksi berat (malaria, sifilis, TBC, HIV), kehamilan post matur (sesudah 42 minggu kehamilan), keracunan obat-obat bius. Faktor tali pusat yang dapat menyebabkan kejadian asfiksia seperti lilitan tali pusat, tali pusat pendek, simpul tali pusat, prolap tali pusat yang mengakibatkan aliran darah ke janin berkurang yang mengakibatkan kejadian gawat janin menyebabkan asfiksia pada bayi baru lahir (Maryunani, 2009).

Serotinus dimaksudkan usia kehamilan telah lebih dari 42 minggu atau lebih sejak hari pertama menstruasi terakhir. Resiko kehamilan lewat waktu antara lain adalah gangguan pertumbuhan janin, gawat janin sampai kematian janin dalam rahim. Permasalahan kehamilan lewat waktu adalah plasenta tidak sanggup memberikan nutrisi dan pertukuran $\mathrm{CO}_{2}$ dan $\mathrm{O}_{2}$ sehingga mempunyai resiko asfiksia sampai kematian dalam rahim (Wiknjosastro, 2007).

Berdasarkan data dan informasi Kementerian Kesehatan RI AKB di Sulawesi Tenggara mencapai 45 per 1.000 kelahiran (Kemenkes RI, 2015). AKB di Kota Kendari pada tahun 2014 sebanyak 26 orang dari 6.228 orang bayi yang baru lahir dengan angka kejadian asfiksia pada bayi baru lahir di Rumah Sakit Umum Kota Kendari pada tahun 2015 sebanyak 78 orang dari 950 bayi yang baru lahir dan jumlah bayi yang mengalami serotinus sebanyak 40 bayi (Rekam Medik RSUD Kota Kendari, 2015). 
Hasil penelitian yang telah dilakukan oleh Erna Eka Wijayanti tahun 2010 menyimpulkan bahwa ada hubungan antara serotinus dengan kejadian asfiksia pada bayi baru lahir di RSUD Dr. R. Koesma Tuban dengan jumlah serotinus sebanyak 12 orang dan jumlah asfiksia pada bayi baru lahir sebanyak 4 bayi (Wijayanti, 2010). Hal ini juga sejalan dengan penelitian yang telah dilakukan oleh Dewi Tangalayuk pada tahun 2011 yang menyimpulkan bahwa ada hubungan antara serotinus dengan kejadian asfiksia pada bayi baru lahir di Rumah Sakit Umum Propinsi Sulawesi Tenggara dengn hasil uji chi square $\mathrm{X}^{2}$ hitung 14,79 > $\mathrm{X}^{2}$ tabel 3,841 (Tangalayuk, 2011).

Berdasarkan latar belakang tersebut, maka perlu dilakukan penelitian dengan judul hubungan serotinus dengan kejadian asfiksia bayi baru lahir di Rumah Sakit Umum Daerah Kota Kendari tahun 2015.

\section{METODE}

\section{Jenis Penelitian}

Jenis penelitian yang digunakan adalah analitik dengan rancangan Case Control.

\section{Lokasi dan Waktu Penelitian}

Penelitian ini telah dilaksanakan di Ruang Bersalin Rumah Sakit Umum Daerah Kota Kendari.

Penelitian ini telah dilaksanakan pada bulan juli tahun 2016 .

\section{Populasi dan Sampel.}

Populasi dalam penelitian ini adalah semua bayi yang dilahirkan di Ruang Bersalin Rumah Sakit Umum Daerah Kota Kendari tahun 2015 berjumlah 950 orang.

Sampel dalam penelitian ini adalah bayi yang mengalami asfiksia dan yang tidak mengalami asfiksia berjumlah 156 bayi.

\section{Pengumpulan Data}

Pengumpulan data pada penelitian ini melalui teknik checklist dan pencatatan dari sejumlah laporan maupun dokumen yang telah disediakan oleh instansi terkait. Sedangkan data pendukung lainya, berupa teori maupun konsep yang dijadikan acuan dalam penelitian ini diperoleh melalui teknik library research, dan membaca hasil-hasil penelitian maupun literatur yang relevan mendukung penelitian ini.

\section{Pengolahan dan Analisis Data}

Data dioleh dan disajikan kemudian dipresentasikan dan diuraikan. Data penelitan dianalisis dengan menggunakan uji Chi-Square.

\section{HASIL}

Berdasarkan data yang terkumpul, jumlah sampel yang diperoleh sebanyak 78 responden. Subjek penelitian dibagi menjadi dua kelompok yaitu kasus (78 bayi baru lahir dengan asfiksia) dan kontrol (78 bayi baru lahir dengan tidak asfiksia). Sampel yang diambil adalah kasus:kontrol (1:1). Hasil penelitian dapat dilihat pada tabel-tabel berikut :

Tabel 1. Distribusi Frekuensi Kejadian asfiksia pada bayi Baru Lahir di Rumah Sakit Umum Daerah Kota Kendari Tahun 2015

\begin{tabular}{ccc}
\hline Variabel & N & \% \\
\hline Asfiksia & 78 & 8,21 \\
Tidak asfiksia & 872 & 91,79 \\
\hline Total & 950 & 100 \\
\hline
\end{tabular}

Sumber: Medical Record RSUD Kota Kendari Tahun 2016

Berdasarkan tabel 1 dapat disimpulkan bahwa jumlah seluruh bayi yaitu sebanyak 950 dimana bayi yang mengalami asfiksia sebanyak
78 orang $(8,21 \%)$ dan bayi yang tidak mengalami asfiksia sebanyak 872 orang (91,79\%). 
Tabel 2. Distribusi Frekuensi Serotinus Pada Bayi Baru Lahir di Rumah Sakit Umum Daerah Kota Kendari Tahun 2015

\begin{tabular}{ccc}
\hline Variabel & $\mathbf{N}$ & $\mathbf{\%}$ \\
\hline Serotinus & 40 & 4,21 \\
Tidak Serotinus & 910 & 95,79 \\
\hline Total & 950 & 100 \\
\hline
\end{tabular}

Sumber: Medical Record RSUD Kota Kendari Tahun 2016

Berdasarkan tabel 2 dapat disimpulkan bahwa jumlah seluruh bayi yaitu sebanyak 950 dimana bayi yang mengalami serotinus sebanyak 40 orang $(4,21 \%)$ dan bayi yang tidak mengalami serotinus sebanyak 910 orang $(95,79 \%)$.

Tabel 3. Hubungan Serotinus Dengan Kejadian Asfiksia pada Bayi Baru Lahir di Rumah Sakit Umum Daerah Kota Kendari Tahun 2015

\begin{tabular}{|c|c|c|c|c|c|c|c|}
\hline \multirow{3}{*}{ Variabel } & \multirow{2}{*}{\multicolumn{2}{|c|}{$\begin{array}{c}\text { Asfiksia } \\
(n=78)\end{array}$}} & \multirow{2}{*}{\multicolumn{2}{|c|}{$\begin{array}{c}\text { Tidak } \\
\text { Asfiksia } \\
(n=78)\end{array}$}} & \multirow{3}{*}{$\mathbf{X}^{2}$} & \multirow{3}{*}{$\begin{array}{c}\text { OR } \\
(95 \% \mathrm{Cl})\end{array}$} & \multirow{3}{*}{$P$} \\
\hline & & & & & & & \\
\hline & $\mathbf{n}$ & $\%$ & $\mathbf{N}$ & $\%$ & & & \\
\hline Serotinus & 10 & 12,8 & 2 & 2,6 & 5,778 & 5,588 & 0,032 \\
\hline Tidak Serotinus & 68 & 87,2 & 76 & 97,4 & & & \\
\hline
\end{tabular}

Keterangan: *: $p$ value $<0,05$ (sugnifikan), $\mathrm{Cl}$ : Convidence Interval

$\mathrm{X}^{2}$ tabel: 3.841

Tabel 3 menunjukkan bahwa setelah dilakukan uji statistik diperoleh nilai $\mathrm{X}^{2}$ hitung $=5,778>\mathrm{X}^{2}$ tabel $=3,841$ sehingga $\mathrm{HO}$ ditolak dan Ha diterima artinya ada hubungan antara serotinus dengan kejadian asfiksia dengan nilai $\mathrm{OR}=5,588>1$ artinya factor yang di teliti merupakan factor resiko. Berdasarkan analisis tersebut maka dapat diinterpretasikan bahwa bayi yang terlahir dengan serotinus 5,588 beresiko untuk terjadinya asfiksia.

\section{PEMBAHASAN}

Hasil analisis univariabel dan bivariabel menunjukkan bahwa ada hubungan antara serotinus dengan kejadian asfiksia pada bayi baru lahir bahwa serotinus merupakan faktor resiko untuk terjadinya asfiksia bayi baru lahir, dimana dari 78 bayi yang mengalami asfiksia terdapat 10 bayi $(12,8 \%)$ lahir dengan serotinus dan 78 bayi yang tidak mengalami asfiksia terdapat 2 bayi $(2,6 \%)$ lahir dengan serotinus sedangkan dari 78 bayi yang mengalami asfiksia terdapat 68 bayi $(87,2 \%)$ lahir tidak serotinus dan dari 78 bayi yang tidak mengalami asfiksia terdapat 76 bayi $(97,4 \%)$ lahir tidak serotinus. Setelah melakukan analisa antara serotinus dengan kejadian asfiksia pada bayi baru lahir di Rumah Sakit Umum Daerah Kota Kendari tahun 2015 terbukti dengan hasil uji chi square $X^{2} \quad 5,778$ dan $X^{2}$ tabel 3,841 sehingga $X^{2}$ hitungan $>X^{2}$ tabel yang berarti H0 ditolak dan Ha diterima, dengan nilai $\mathrm{OR}=5,588>1$ artinya factor yang di teliti merupakan factor resiko. Hasil penelitian ini sesuai dengan teori Wiknjosastro (2007) bahwa salah satu faktor penyebab terjadinya asfiksia pada bayi baru lahir dikarenakan serotinus.

Hal ini juga sejalan dengan penelitian yang telah dilakukan oleh Dewi Tangalayuk pada tahun 2011 yang menyimpulkan bahwa ada hubungan antara serotinus dengan kejadian asfiksia pada bayi baru lahir di Rumah Sakit Umum Propinsi Sulawesi Tenggara dengan hasil uji chi square $\mathrm{X}^{2}$ hitung 14,79 dan $\mathrm{X}^{2}$ tabel 3,841 sehingga $X^{2}$ hitung $>X^{2}$ tabel yang berarti $\mathrm{H} 0$ ditolak dan $\mathrm{Ha}$ di terima. ini menunjukan bahwa serotinus merupakan factor dari penyebab terjadinya asfiksia (Tangalayuk, 2011).

\section{KESIMPULAN DAN SARAN}

Ada hubungan antara serotinus dengan kejadian asfiksia pada bayi baru lahir di Rumah Sakit Umum Daerah Kota Kendari tahun 2015. Terbukti dengan hasil uji chi square $\mathrm{X}^{2}$ hitungan $5,778>\mathrm{X}^{2}$ tabel 3,841 dengan nilai $\mathrm{OR}=5,588$. Bayi yang terlahir 
dengan serotinus 5,588 beresiko untuk terjadinya asfiksia.

Perlunya penelitian yang lebih mendalam tentang faktor-faktor lain yang berhubungan dengan asfiksia bayi baru lahir dengan variabel lain yang belum diungkapkan sehingga didapatkan hasil yang lebih luas dan mendalam. Pada pihak rumah sakit perlu adanya pertolongan persalinan yang tepat dan cepat pada persalinan beresiko tinggi sehingga kegawatdaruratan pada janin dapat diminimalkan.

\section{DAFTAR PUSTAKA}

Adhyatama, M. 1998. Ibu dan Anak Sebagai Kelompok Sasaran Utama dalam Penurunan AngkaKematian Bayi dan Anak.Majalah Kesehatan. 116:6-10.

Briley\& Annette. 2006. Asuhan Kebidanan Pada Persalinan : Preeklampsia. Jakarta: Penerbit Buku Kedokteran, EGC.

Bobak, I. M. 2005. Buku Ajar Keperawatan Matematis. Jakarta: EGC.

Hacker, F. \& Neville. 2001. Esensial Obstetri dan Ginekologi. Jakarta: Hipokrates.

Hanafiah, M.I. 1986. Pelayanan Perinatologi Ditinau Dari Segi Obstetri. Kumpulan Naskah Lengkap Kongres Nasional Perinasia II. Surabaya.

Ivone, S. 1999. Faktor Resiko Terjadinya Kematian Ibu Oleh Karena Preeklampsia-Eeklampsia Di Rumah Sakit Umum Tangerang Tahun 1999. Karya Tulis Ilmiah. Tangerang.

Kementerian Kesehatan Republik Indonesia. 2011. Profil Kesehatan Indonesia Tahun 2010. Jakarta.

Kementerian Kesehatan Republik Indonesia. 2015. Profil Kesehatan Indonesia Tahun 2014. Jakarta.

Manuaba, I. B. G.1998.Ilmu Kebidanan Penyakit Kandungan dan Keluarga Berencana untuk Pendidikan Bidan. Bab 5. Hal 265. Jakarta: EGC.

Maryunanii. 2009.Asuhan Kegawatdaruratan dalam Kebidanan. Jakarta: Trans Info Media.
Maryuni, A. 2009. Asuhan Kegawatdaruratan dan Penyulit Pada Neonatus. Jakarta:Trans Info Media.

Proverawati. 2010. Berat Badan Lahir Rendah. Yogyakarta:Nuha Medika.

Rekam Medik RSUD Kota Kendari. 2015. Rekapitulasi Kejadian Asfiksia Pada BAYI Baru Lahir tahun 2015. Rumah Sakit Umum Daerah Kota Kendari.

Rustam, M. 1998.Sinopsis Obstetri. Jilid I. . Jakarta: EGC.

Saifuddin, A.B. 2002. Buku Acuan Nasional Pelayanan Kesehatan Maternal Dan Neonatal. Jakarta. Yayasan Bina Pustaka Sarwono Prawirohardjo.

Straight, B. R.2004.Keperawatan Bayi Baru Lahir. Edisi 3. Jakarta: EGC.

Suromo, L.B., Kosim, M.S. \& Rini, A.E. 2010. Faktor Risiko Air Ketuban Keruh Terhadap Kejadian Sepsis Awitan Dini Pada Bayi Baru Lahir. Semarang: Ilmu Kesehatan Anak FK Universitas Diponegoro.

Syafrudin. 2009. Hubungan Partus Lama Dengan Kejadian Asfiksia Neonatorum di Rumah Sakit Umum Daerah dr. R. Koesma Tuban tahun 2009. http:wordpress.com./category/ktikebidanan.

Tangalayuk, D. 2011. Hubungan Serotinus Dan Partus Lama Dengan Kejadian Asfiksia Pada Bayi Baru Lahir Di Rumah Sakit Umum Provinsi Sulawesi Tenggara Tahun 2010. Karya Tulis Ilmiah. Politeknik Kesehatan Kendari.

Wibowo, B. \& Rachimhadi, T. 1997. Ilmu Kebidanan; Preeklampsia dan Eklampsia. Jakarta: Yayasan Bina Pustaka Sarwono Prawirohadjo.

Wijayanti, E.E. 2010. Hubungan Kehamilan Lewat Waktu Dengan Kejadian Asfiksia Bayi Baru Lahir di RSUD dr. R. Koesma Tuban. STIKES NU Tuban.

Wiknjosastro, H.2007.Pelayanan Kesehatan Maternal dan Neonatal. Jakarta: Yayasan Bina Pustaa.

Yulianti, L. 2009.Asuhan Kebidanan II. Jakarta: Trans Info Media. 